Research, part of a Special Feature on Cooperation, Local Communities, and Marine Social-ecological Systems: New Findings from Latin America

\title{
Cooperative and Noncooperative Strategies for Small-scale Fisheries' Self-governance in the Globalization Era: Implications for Conservation
}

\author{
$\underline{\text { Xavier Basurto }}^{1}, \underline{\text { Abigail Bennett }}^{1}, \underline{\text { Amy Hudson Weaver }}^{2}, \underline{\text { Salvador Rodriguez-Van Dyck }}^{2}$ and $\underline{\text { Juan-Salvador Aceves-Bueno }}^{2}$
}

\begin{abstract}
Fishing cooperatives (co-ops) and patron-client relationships are the most common cooperative and noncooperative strategies for self-governance for small-scale fisheries around the world. We studied what drives fishers to choose between these two self-governance arrangements in 12 communities in the Gulf of California, Mexico. The communities depend on similar fishing resources, are located in contiguous portions of the coast, fish roughly the same species, have similar socioeconomic characteristics, and sell to similar markets, yet half of the fisheries are organized around co-ops and the other half work through patron-client arrangements. Using participant observation, in-depth interviews of key informants between 1995-2008, and a survey of $55 \%$ of the fisheries in the study area, we found that the presence of high transaction costs of commercialization, the desire to acquire fishing licenses, and the existence of traditions of successful collective action among fishing groups within each community strongly influence fishers' choices regarding membership in fishing co-ops. We also examined the implications of our findings for conservation of fishing resources. Given that the emergence of co-ops was associated with high transaction costs of commercialization, we hypothesize that cooperative strategies are more likely than patron-client strategies to emerge in communities in isolated locations. In an era of globalization, in which the rate of development and urbanization will increase in coastal areas, patron-client strategies are likely to become more prevalent among fisheries, but such self-governance strategies are thought to be less conducive to conservation behaviors.
\end{abstract}

RESUMEN. Las cooperativas pesqueras y los arreglos informales directos entre el pescador y el comprador son las estrategias de cooperación y no cooperación más comunes de la autogobernanza de la pesca artesanal a escala global. Investigamos cuáles son los factores que influyen en la elección de los pescadores entre una y la otra, en doce comunidades del Golfo de California, México. Todas las comunidades del área de estudio son semejantes ya que dependen de los mismos recursos pesqueros, se ubican en una zona costera contigua, por lo general capturan las mismas especies, presentan características socioeconómicas similares y comercializan en mercados equivalentes. Sin embargo, casi la mitad de los pescadores se ha organizado en cooperativas y la otra mitad de manera individual en arreglos informales directos con los compradores. Para entender el contexto de la localidad, entre 1995 y 2008 utilizamos técnicas de observación participativa y entrevistas a fondo con informantes clave, así como una encuesta aplicada al 55\% de los pescadores del área de estudio. Descubrimos que la existencia de altos costos de transacción para la comercialización del producto, el deseo de obtener permisos de pesca artesanal comercial y las tradiciones de acción colectiva de los diferentes grupos pesqueros en cada comunidad, influye sobremanera en la estrategia de la autogobernanza elegida por los pescadores. También examinamos cuáles son algunas de las implicaciones de estos resultados en la conservación de los recursos pesqueros. Dado que el surgimiento de las cooperativas pesqueras estaba asociado a los altos costos de transacción para la comercialización del producto, planteamos como hipótesis que las estrategias de cooperación son más probables en comunidades aisladas que las de no cooperación. No obstante, en la era de la globalización en la que la tasa de desarrollo e urbanización aumentará en las áreas costeras, probablemente las estrategias de no cooperación se vuelvan más frecuentes en el ámbito pesquero, aunque se considera que dichas estrategias no favorecen al comportamiento compatible con la conservación de los recursos.

Key Words: commercialization; fishing cooperatives; Gulf of California fisheries; location and co-op choice; resource stewardship; self-governance; small-scale fisheries

\section{INTRODUCTION}

Robust stewardship of social-ecological systems is associated with the local capacity to develop enduring governance arrangements (Folke et al. 2002, Ostrom 2009). Small-scale fisheries (SSFs) are social-ecological systems supporting millions of fishers around the globe, mostly in developing countries (Delgado et al. 2003). SSFs play an important role in food security, poverty alleviation, and biodiversity conservation in coastal communities (Chuenpagdee 2011).

In regions where formal regulatory capacity is weak and is focused primarily on the industrial sector, patterns of SSFs production, commercialization, and governance are often structured by a diversity of self-governed arrangements

${ }^{1}$ Duke University, ${ }^{2}$ Sociedad de Historia Natural Niparajá, A.C. 
(Chuenpagdee 2011). In the context of SSFs, we view selfgoverned arrangements as those where individuals involved in fishing activities take on the duties of designing agreements related to fishing production and commercialization, and monitor and enforce their commitments to each other without resorting to the state or other external authorities. Understanding what kind of governance arrangements enable local people to adapt to environmental and institutional variability to sustain their livelihoods will be increasingly important in the face of global change (Berkes and Folke 1998, Armitage et al. 2007).

Broadly construed, fishing communities can self-govern through either cooperative or noncooperative strategies. In this paper we study the factors that influence fishing communities' choices of cooperative or noncooperative self-governance arrangements. We explore how the resultant organizational forms might affect fishing communities' potential capacity for conservation.

Successful participation in commercially oriented SSFs entails a set of tasks beyond fishing itself. These tasks include obtaining and maintaining fishing means of production, accessing property rights to the fishery such as permits or concessions, and partaking in transporting and selling catch. Each of these tasks is associated with direct and indirect costs, which, in sum, are generally beyond the means of any individual fisher. As a result, some form of coordination and organization, either through a division of labor, sharing of costs, or both, is most often necessary. Cooperative and noncooperative organizational strategies can be distinguished according to the manner and extent to which costs, duties, and property rights are shared.

We recognize that there are many forms and shades of cooperative and noncooperative self-governance arrangements among fishing communities, but for the purposes of this research we make the following distinctions: cooperative strategies are those most easily recognized when fishers formally contract with others and determine the roles and responsibilities of working collectively as a formalized group like a fishing cooperative, or co-op. A co-op is usually defined as an autonomous association of persons united voluntarily to meet their common economic, social, and cultural needs and aspirations through a jointly owned and democratically controlled enterprise (FAO 1971, Sapovadia 2004, ICA 2010). Cooperative strategies require collective action to coordinate the joint sharing of the transaction costs associated with the extraction and/or commercialization of their catch (Jentoft 1986). Usually, property rights to fisheries resources are owned in common by the co-op, and collective action is needed to ensure that individuals do not shirk duties or otherwise undermine the group's efforts. Fishing cooperatives are ubiquitous examples of cooperative strategies. In Turkey, one in every four fishers belongs to a co-op (Unal et al. 2009). In
Mexico, officials estimate the existence of more than 3200 coops (Juárez-Torres et al. 2007), and more than 620 fisher's syndicates are reported in Chile (Marín et al. 2012).

In contrast, under a noncooperative strategy, such as a patronclient relationship, a fishing crew does not engage with others in collective action to coordinate and share the transaction costs associated with harvesting or commercialization, nor do they formally contract with each other (Wang 1999). Instead, individual fishers engage in informal agreements with fish buyers to buy their catch (Merlijn 1989). Johnson (2010:265) describes this form of self-governance arrangement as "common economic arrangements ... that link powerful individuals with numerous subordinates. In exchange [for] favors, including loans, protection, or intermediation, patrons receive labor, goods, political support or other benefits."

As we will see, previous research suggests that state regulations and other potential benefits incentivize fishers to self-govern their fisheries through fishing co-ops, while also arguing that markets incentivize fishers to forgo the costs and challenges of sustained collective action and organize their activities through patron-client interactions with middlemen or fish buyers. Both forms of self-governance arrangements are common around the world. To better understand what factors influence the choice between cooperative and noncooperative governance arrangements, we conducted a comparative study of 12 permanent small-scale fishing communities in the Gulf of California, Mexico.

About half of the fishers in the study area are self-organized through co-ops and the rest are organized through patron-client relations. However, all communities depend on similar fishing resources, are located in a contiguous portion of the coast, fish roughly the same species, have similar socioeconomic characteristics, and sell to similar markets. As we will explain, our findings suggest transaction costs of commercialization, access to fishing licenses, and long-standing traditions of successful collective action strongly influence the fishing communities' choices of self-governance arrangements.

\section{Drivers of self-governance arrangements in fisheries}

It is often stated that fishers' main motivation to organize into co-ops is accessing fishing property rights (e.g., fishing permits, concessions), subsidies, and credits for fishing gear. In some cases, the state provides these benefits exclusively to co-ops (McGoodwin 1980, Kurien 1988, Dominguez 1995, Baticados 2004, Cheong 2004). However, other benefits that fishers obtain from fishing co-ops have also been documented: economic development and poverty alleviation in coastal communities (Jentoft 1986); access to educational, jobtraining opportunities, and information about fishery regulations (Lindenthal 1994); devolution of power to local stakeholders in managing local fishing resources (Amarasinghe 2006, Lejano and Ocampo-Salvador 2006); increasing local participation in different aspects of the fishing 
process, including production and commercialization (Pollnac 1985); and ecological conservation (Ovando et al. 2012).

In patron-client relationships, fishers avoid the transaction costs of commercialization and costs of obtaining and maintaining fishing property rights. It is through providing their labor to the patrons that fishermen can gain access to fishing property rights, personal loans, and informal subsidies (Merlijn 1989). Around the world, variations to this general pattern are found (Barrett and Apostle 1989), from fishers who own their boat and fishing gear but informally contract with a middleman or fish buyer to commercialize and legalize their catch through the fish buyers' permit (Ruddle 2011) to fishers who depend entirely on the patron's ability to provide them with fishing means of production and to shelter their catches under their permits. Under the latter arrangement, however, fishers have less power to influence decision making related to the fishing sector, because only permit holders are recognized by the state as stakeholders (Cinti et al. 2010). Fishers are also easily engaged in illegal fishing practices when patrons assure them they will buy their products even if formal regulations are not met (Pedroza 2013). Exploitative relations are common in places with little to no competition or monopsonies (Barrett and Apostle 1989), although nonexploitative relations have also been reported (Ruddle 2011). In sum, the persistence of patron-client relations relies not so much on collective action, but rather on the entrepreneurship and economic power of the patron and his or her ability to enforce informal contractual agreements with fishermen.

\section{Social-ecological and institutional setting}

The study area encompasses 12 permanent fishing communities located in the Gulf of California, Mexico (Fig. 1), in a region labeled as the Corridor San Cosme to Punta Coyote. The corridor encompasses the last remaining $150 \mathrm{~km}$ stretch of scarcely inhabited coast between the touristic town of Loreto and the city of La Paz, the state capital of Baja California Sur. This area was selected because fishermen have chosen both cooperative and noncooperative strategies to organize their activities here. Furthermore, all communities in the corridor show characteristics that distinguish them from other regions nearby: dependence on marine resources, varying isolation, small size, similarity of fishing traditions, i.e., species targeted and fishing techniques, lack of presence of governmental authority, and relative socioeconomic homogeneity.

The corridor is a remote and difficult-to-access region with only two dirt roads that are passable all year round. Five of the communities can only be accessed by sea (Fig. 2). None of the communities has municipal public services or electricity. Only the communities of Agua Verde, Tembabiche, and Ensenada de Cortés have running water, and San Evaristo has a desalinization plant. Fishing is the most important economic activity, and $91 \%$ of the fishers do not have any other source of income. In the 12 communities, there are a total of 168 permanent fishers, representing about $30 \%$ of the total inhabitants $(n=630)$; they employ 94 pangas, 7 to $9 \mathrm{~m}$ long outboard motorboats. The number of pangas in each community ranged from 1 to 36 . Most fishers (93\%) proudly use hook and line as their main fishing gear, but $30 \%$ also use gillnets, and only $7.3 \%$ use hookah diving gear and/ or longlines. Fishers target about 46 different species, but the most important is the huachinango, the red snapper (Lutjanus peru; Fig. 2). The catch for all 12 communities is landed in only 5 communities: Agua Verde, Tembabiche, San Evaristo, El Portugués, and Punta Coyote (Fig. 1). In all, $51 \%$ of fishers are members of fishing co-ops, and $49 \%$ are organized under a patron-client relationship (Table 1).

Fig. 1. The corridor study area showing fishing communities and routes to nearest market destinations.

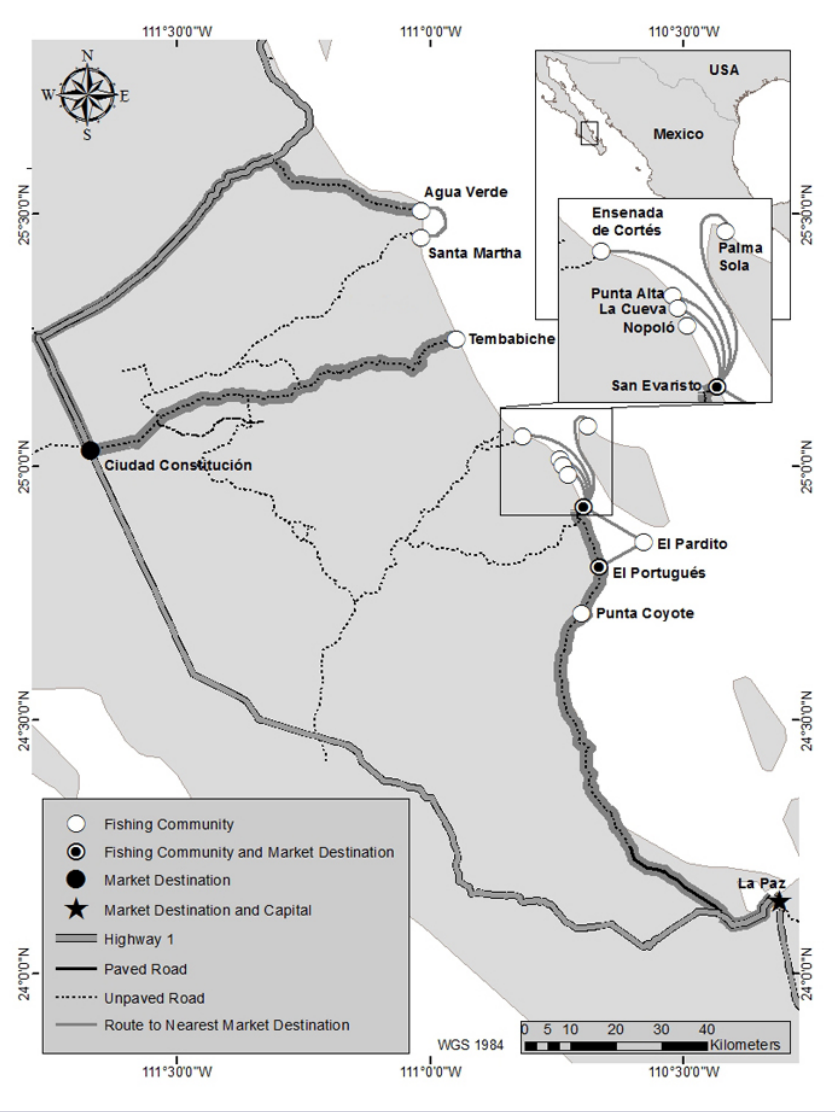

From a historic perspective, Mexico has long favored a state policy of interventionism and protectionism to incentivize the formation of fishing co-ops (McGoodwin 1980). In 1992, however, the fisheries law was modified to attract foreign investment (Toledo and Bozada 2002), allowing individuals outside co-ops to obtain fishing permits (Cinti et al. 2010) and to qualify for government loans and subsidies. The National Commission of Fisheries and Aquaculture (CONAPESCA), 
Table 1. Characteristics of the study area and its communities.

\begin{tabular}{|c|c|c|c|c|c|c|c|}
\hline Community & Landing site & Fishers in co-ops & $\begin{array}{c}\text { Co-op name(s) } \\
\text { (year of formation) }\end{array}$ & $\begin{array}{c}\text { Number of } \\
\text { pangas }\end{array}$ & $\begin{array}{c}\text { Number } \\
\text { of fishers }\end{array}$ & Main species fished & $\begin{array}{c}\text { Fishing gear used } \\
(\%)\end{array}$ \\
\hline $\begin{array}{l}\text { Entire Corridor } \\
\text { Region }\end{array}$ & 5 Total & $\begin{array}{l}(51 \% \text { of all } \\
\text { fishers in the } \\
\text { region })\end{array}$ & $\begin{array}{l}\text { See co-op names by } \\
\text { community below }\end{array}$ & 94 Total & $\begin{array}{c}168 \\
\text { Total }\end{array}$ & $\begin{array}{c}\text { Huachinango }^{\dagger} \\
\text { Pargo mulato } \\
\text { Jurel }^{\S} \\
\text { (of } 46 \text { total species) }\end{array}$ & $\begin{array}{c}\text { Hook-and-line }(93 \%) \\
\text { Gillnets }(30 \%) \\
\text { Other (hookah diving gear, } \\
\text { longlines }(7.3 \%)\end{array}$ \\
\hline Agua Verde & Yes & Yes & $\begin{array}{c}\text { Islote Agua Verde } \\
\text { (2003) } \\
\text { Playas del Puertito } \\
(2006) \\
\text { Roca Solitaria (2003) }\end{array}$ & 36 & 65 & & \\
\hline Santa Martha & No & No & N/A & 1 & 2 & & \\
\hline Tembabiche & Yes & Yes & $\begin{array}{c}\text { Coral de Tembabiche } \\
\text { (2010) } \\
\text { Isla Santa Cruz } \\
(2003)\end{array}$ & 12 & 23 & & \\
\hline E. de Cortés & Yes & No & N/A & 6 & 11 & & \\
\hline Palma Sola & No & No & N/A & 5 & 7 & & \\
\hline Punta Alta & No & Yes & $\begin{array}{c}\text { Isla San Jose } \\
\text { (pre-2008) }\end{array}$ & 7 & 12 & & \\
\hline La Cueva & No & No & N/A & 4 & 6 & & \\
\hline Nopoló & No & No & N/A & 1 & 2 & & \\
\hline San Evaristo & No & No & N/A & 10 & 16 & & \\
\hline El Pardito & No & No & N/A & 6 & 11 & & \\
\hline Portugués & Yes & No & N/A & 1 & 2 & & \\
\hline Punta Coyote & Yes & Yes & $\begin{array}{c}\text { San Juan de la Costa } \\
\text { (pre-2008) }\end{array}$ & 5 & 11 & & \\
\hline
\end{tabular}

${ }^{\dagger}$ Lutjanus peru (red snapper); ${ }^{\ddagger}$ Hoplopagurus guentherii (barred pargo); ${ }^{\S}$ Seriola lalandi dorsalis (yellowtail)

the primary agency in charge of fisheries regulation and enforcement at a national level, is in charge of issuing fishing permits. Legally, fishers may only use fishing equipment, that is, boat, motor, and fishing gear, that is registered in their permits and must commercialize their catch according to the specifications of their permits. Only permit holders can provide invoices to legally land the catch and report it at CONAPESCA. These invoices are necessary to sell, buy, or transport the catch to regional or international markets.

\section{METHODS}

From 1995 to 1996 , Weaver established residence in the region, using the communities of El Pardito and Agua Verde as focal centers; from 2006 to 2008, Rodriguez-Van Dyck and Aceves-Bueno established residence in the same places. During this time, we conducted participant observation (recorded in field journals), informal in-depth interviews with key informants to build understanding over time about fishing and commercialization issues and other aspects related to community life in this region. Eventually, it became feasible to design a comprehensive survey instrument for $55 \%(n=86)$ of all permanent fishers in the study area $(n=168)$. The survey was pretested with four fishers in early 2009 and was fully deployed by enumerators between August and November of 2009. Each interview took, on average, 2.7 hours and covered a range of topics, summarized in Appendix 1. In 2010 and 2012, we conducted subsequent data collection efforts to update survey findings and assess the role of access to fishing permits as a motivator of co-op formation. Survey data were used to examine the role of other potential drivers of co-op formation mentioned in the literature:

1. Access to better market prices for catch: whether fishers organized in co-ops obtained better prices for their catch than those not in fishing co-ops (Appendix 2).

2. Improved access to fishing means of production: whether fishers organized in co-ops owned their own gear, motors, or pangas more often than other fishers (Appendix 2).

3. Access to diverse fishing gear: whether fishers organized in co-ops utilized more gear types than other fishers (Appendix 2).

4. Access to information: whether fishers organized in coops obtained information about the fishery and fishing regulations more often and from different sources than other fishers (Appendix 2).

Before this study was conducted, very little information was available about this region; the characteristics of the study area presented in the previous section resulted from the survey we conducted. In-depth interviews with key informants were used to obtain information about the role of transaction costs of commercialization and the traditions of successful collective action as potential drivers of co-op formation, factors mentioned in the literature as influential for the formation and 
Fig. 2. Social-ecological characteristics of the study area. Clockwise: (a) Community of El Pardito. (b) Community of Punta Alta. (c) Huachinango (red snapper Lutjanus peru). (d) Only two roads are passable year-round. Photo credits: Juan-Salvador Aceves-Bueno (a) and (b), José Manuel Rondero (c), and Salvador Rodríguez (d).
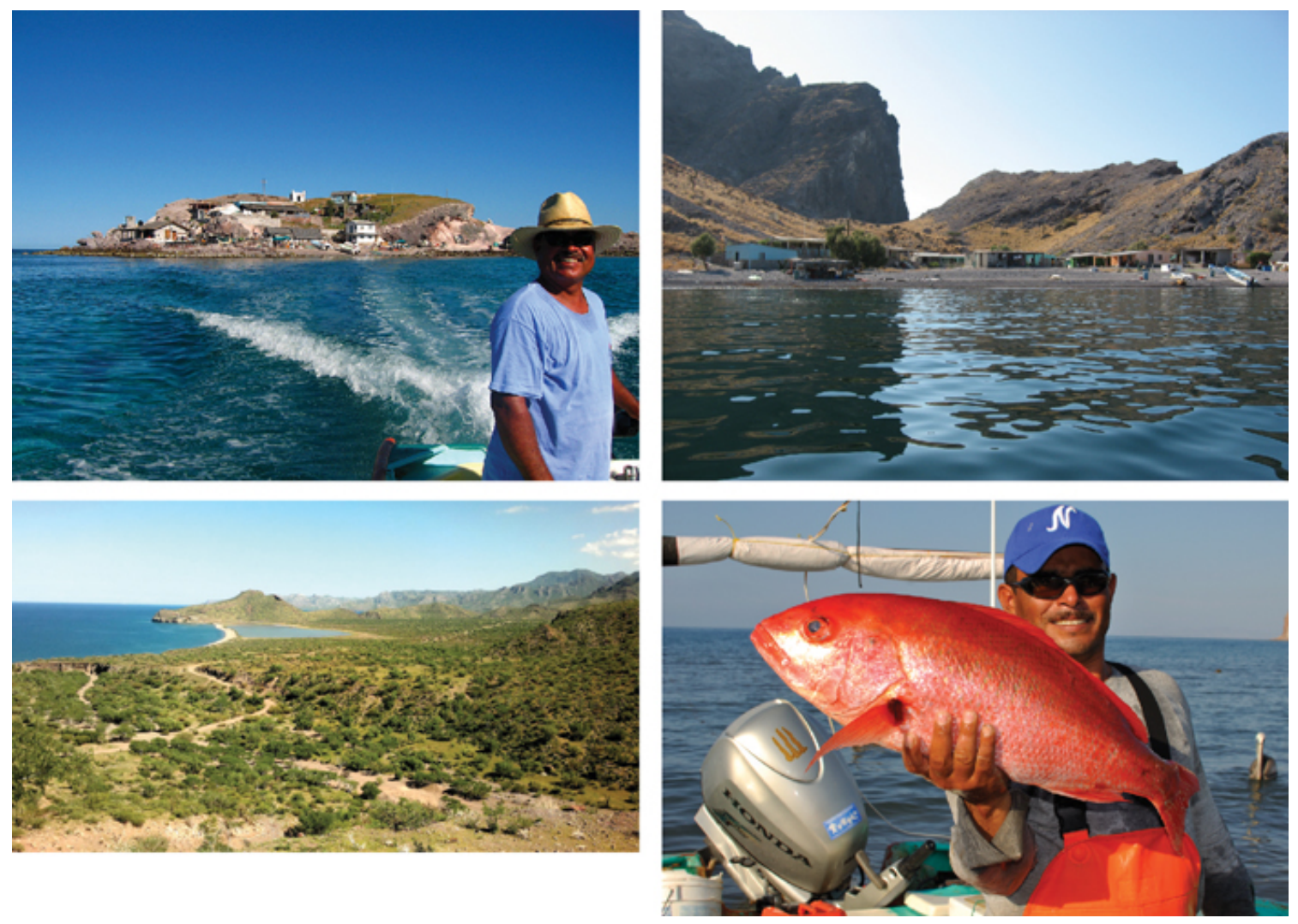

success of patron-client relations (Wang 1999) and co-ops (Poggie et al. 1988).

\section{FINDINGS}

\section{Access to markets, fishing gear, and information}

Fishers organized in co-ops and those in patron-client relationships did not differ in terms of market prices obtained for their catch, access to fishing means of production, or diversity of gear used. As for access to sources of information, fishers in co-ops relied more on information from meetings and from authorities, and fishers organized in patron-client relationships relied more on information from fishers outside of the respondent's community. See Appendix 2 for this data analysis.

\section{The role of fishing permits}

We found seven fishing co-ops in the study area. Key informants and fishers at each cooperative stated that access to fishing permits was the main reason for forming the co-ops. These accounts are corroborated by 2012 survey information about the distribution of fishing permits between fishers within and outside of co-ops (Table 2).

Table 2. Total number of fishing permits, pangas, and fishers by community in the study area and those associated with fishing co-ops.

\begin{tabular}{lcccc}
\hline \hline Community & $\begin{array}{c}\text { Presence } \\
\text { of co- } \\
\text { op }\end{array}$ & $\begin{array}{c}\text { Total \# of } \\
\text { fishing permits } \\
\text { (\# in co-ops) }\end{array}$ & $\begin{array}{c}\text { Total \# of } \\
\text { pangas } \\
\text { (\# in co-ops) }\end{array}$ & $\begin{array}{c}\text { Total \# } \\
\text { fishers } \\
\text { (\# in co-ops) }\end{array}$ \\
\hline Agua Verde & Yes & $17(17)$ & $36(34)$ & $65(59)$ \\
Santa Martha & No & $0(0)$ & $1(0)$ & $2(0)$ \\
Tembabiche & Yes & $6(6)$ & $12(11)$ & $23(19)$ \\
E. de Cortés & No & $2(0)$ & $6(0)$ & $11(0)$ \\
Palma Sola & No & $3(0)$ & $5(0)$ & $7(0)$ \\
Punta Alta & Yes & $6(6)$ & $7(3)$ & $12(6)$ \\
La Cueva & No & $2(0)$ & $4(0)$ & $6(0)$ \\
Nopoló & No & $0(0)$ & $1(0)$ & $2(0)$ \\
San Evaristo & No & $0(0)$ & $10(0)$ & $16(0)$ \\
El Pardito & No & $0(0)$ & $6(0)$ & $11(0)$ \\
Portugués & No & $0(0)$ & $1(0)$ & $2(0)$ \\
Punta Coyote & Yes & $1(1)$ & $5(3)$ & $11(3)$ \\
\hline
\end{tabular}


The role of transaction costs of commercialization

Informal interviews with fishers indicated that fish buyers and middlemen have traditionally not traveled consistently to the more isolated communities to buy their fish. Observations show that fishers have overwhelmingly organized around patron-client relationships in communities characterized by frequent and consistent presence of patrons, or fish buyers. We investigated whether communities more isolated from markets and fish buyers might face incentives to organize around co-ops to lower the transaction costs of transporting the catch to the market. We characterized each community by investigating the variation in its isolation. We accounted for the presence of fish buyers in each community, and compared the costs fishers incurred from traveling by land and sea to reach the first point of commercialization of their catch (Appendix 3, Table A3.1). We found a higher proportion of fishers belonging to co-ops in communities where the transaction costs of commercialization were higher than in communities associated with lower transaction costs (Appendix 3).

\section{Working together as a form of successful collective action}

Participant observers and key informants spoke eloquently about the importance of collective action to sustain their livelihoods in these desert coastal environments. Key activities included transporting freshwater to their communities or houses, digging trenches to lay a water line from a newly constructed well to a house, moving and securing fellow fishers' boats during storms, repairing roads after heavy rains, and taking their catch to the market. All seven fishing co-ops in the study area had developed a working relationship among their members before organizing as co-ops. In some instances, internal differences in the communities initially unified particular groups and then a tradition of working together developed. At the beginning, fishers formed informal working groups along family or religious lines, or by types of activities conducted by different groups in relation to fishing or nonfishing activities such as conducting illegal activities or making efforts to counter illegal activity. In other instances, groups were initiated by an entrepreneur motivated to make money by pooling fish from the community and commercializing it in the nearest market. In still other instances, fishers expressed a collective desire to work together and better their economic condition as a group. Fishers stated that they enjoyed working with other fishers who have reputations as being "skilled" or "good workers."

To summarize, our findings suggest that fishers are most incentivized to organize around co-ops when they live in communities with high transaction costs for accessing markets, and where traditions of working together are present, as well as motivation to gain access to fishing permits (Table 3). We describe how these drivers combine in different ways in the different communities in our study area.
Table 3. Conditions driving the emergence of co-ops in the studied communities. Note number of co-ops per community in parentheses.

\begin{tabular}{lcccc}
\hline \hline Community & $\begin{array}{c}\text { Most fishers } \\
\text { have fishing } \\
\text { permits? }\end{array}$ & $\begin{array}{c}\text { High } \\
\text { transaction } \\
\text { costs of } \\
\text { commerciali- } \\
\text { zation }\end{array}$ & $\begin{array}{c}\text { Traditions of } \\
\text { working } \\
\text { together }\end{array}$ & $\begin{array}{c}\text { Are there co- } \\
\text { ops in the } \\
\text { community? }\end{array}$ \\
\hline Agua Verde & Yes & Yes & Yes & Yes (3) \\
Santa Martha & No & No & Yes & No \\
Tembabiche & Yes & Yes & Yes & Yes (2) \\
E. de Cortés & No & No & Yes & No \\
Palma Sola & No & No & Yes & No \\
Punta Alta & Yes & No & Yes & Yes (1) \\
La Cueva & No & No & Yes & No \\
Nopoló & No & No & Yes & No \\
San Evaristo & No & No & No & No \\
El Pardito & No & No & Yes & No \\
Portugués & No & No & NA & No \\
Punta Coyote & Yes & Yes & Yes & Yes (1) \\
\hline
\end{tabular}

Permits obtained before 2011

\section{DISCUSSION}

\section{How drivers combine into cooperative versus noncooperative forms of self-governance}

The influence of traditions of successful collective action All communities where fishers formed co-ops also evidenced the presence of traditions of successful collective action (Table 3 ). The presence of this factor has been linked to wellfunctioning co-ops in other regions of Mexico (Castañeda et al. 2012) and elsewhere (Poggie et al. 1988), and more generally has been linked to successful governance for the sustainability of common-pool resources (Ostrom 2009).

In Tembabiche, one group of fishers developed a tradition of working together along family lines. Another group was integrated by fishers who bonded through their desire to not be associated with fishers involved in illegal activities. Both groups formally organized into their own co-ops when the need to gain access to a fishing permit or to share the costs of commercializing their catch arose. As a result of their previous interactions, establishing these co-ops did not imply that they would incur significant transaction costs of developing new relationships with fellow fishers. They already knew what to expect from each other in aspects related to their fishing activities. For instance, the individual who was selected to be the co-op president had previously been a construction worker, brought in to build the community school. Through his interactions in the community, he developed a reputation as a good administrator, and fishers asked him to stay and preside over the co-op, handling all administrative and managerial issues. 
Traditions of working together to solve the collective task of getting the fish to market sometimes spill outside the bounds of co-ops. In the community of Punta Alta, where half (6/12) of all the fishers in the community are organized around a coop (Fig. 2b and Table 2), fishers must transport their catch by boat to the middleman who buys it from them, although the transaction costs Punta Alta fishers face to reach this first point of commercialization are not high (Table 3). Fishers who belong to the co-op coordinate with nonmembers, taking turns to deliver the fish. In this community, relationships based on trust and reciprocity have extended outside of the co-op to include other members of the community considered to be trustworthy who are facing the same collective problem of reaching the market.

Working together has not always motivated fishers to organize into co-ops. Indeed, negative experiences have had the opposite effect. This was the case of El Pardito (Fig. 2a and Table 3), in which the community developed a tradition of working together and eventually organized as a co-op, but the co-op was dissolved long before this study began. The patriarch of the community managed the co-op as a "dictator," commanding all internal decision making, including how much money each member should make for their efforts. The day he died, the co-op was dissolved. The experience left this community with no appetite to work together as a co-op again. Currently, individual fishers of El Pardito have acquired their own fishing permits and, with low transaction costs to commercialize their catch, fishers see no benefit to formally organize. In their view, the best organizational strategy is to sell individually to a fish buyer.

There are cases like San Evaristo, where a tradition of fishers working together to solve collective-action problems has never developed (Table 3). In these places, it is characteristic that fishers face low transaction costs of commercializing their catch. Constant presence of fish buyers and easy access to the capital city of La Paz may crowd out the need for individual fishers to engage in collective action outside of their small fishing crews. As in El Pardito, individual fishers see no need to organize around co-ops. As an informant put it, working under a patron-client structure is "easier" and is how "things are done around here."

\section{Fishing permits and high transaction costs of commercialization}

In all of the communities, informants stated that the need to access fishing permits influenced them to form co-ops (Table 3). Generally, individuals seeking to make a living from selling fish as middlemen have an incentive to be in possession of a fishing permit, otherwise catch cannot legally be sold further down the supply chain. However, fishers have multiple options. They can either pursue an individual fishing permit, form a co-op to obtain a collectively owned permit, or work informally under the umbrella of a patron's fishing permit. In communities facing high transaction costs of commercializing their catch due to their isolation and a lack of consistent fish buyers, noncooperative strategies are very costly to each individual fisher. The best individual strategy for a fisher seeking to sell fish is to persuade other fishers to form a coop together. In Agua Verde, for instance, a fisher with a truck decided to make a living selling fish by pooling catches from other fishers in the community and transporting it to Ciudad Constitución, the closest market destination to the community (Fig. 1). Because he needed to get a fishing permit and secure a reliable supply of fish, he saw it in his interest to formally organize fishers into a co-op, with whom he had family ties and a long-standing working relationship, and become its president. Fishers also saw a benefit from this arrangement in that it would allow them to have a collectively owned fishing permit and move away from fishing illegally in their own traditional fishing grounds. It was a win-win situation for both parties, and although fishers often complain that the president does not communicate to them much about the co-op's finances and business in general, fishers do not leave the coop. Although this co-op essentially operates as a patron-client scheme, it is the best arrangement for all involved.

In contrast, other fishers in Agua Verde did not join this coop because they viewed its president as purely self-interested. They did not see any individual or collective benefit from being part of the co-op and decided to form their own. This co-op is regarded as having the most ambitious and best-skilled fishermen among its ranks, and members seem to be characterized by a collective desire to work together and better their economic conditions as a group.

\section{Implications for conservation}

Fit is the degree to which a particular governance system is compatible with the biogeophysical system with which it interacts (Young 2002). Some governance arrangements seem to offer better social-ecological fit and potential for adaptation to environmental and institutional variability than others. Our study suggests that fishing co-ops in the study area are better fitted to isolated settings facing high transaction costs in reaching the first point of commercialization, settings that also have traditions of successful collective action and social norms that might compel fishers to legalize their work by obtaining a fishing permit. As Wang (1999) points out, places of high transaction costs for reaching the first point of commercialization are associated with the absence in the community of middlemen or fish buyers. Given the powerful role middlemen can play to shape economic and political interactions, and their potential for altering existing local social networks that support the emergence or sustainability of collective action (Stuster 1980), absence of middlemen might positively influence the development or sustainability of traditions of fishers working together to solve the collective challenge of getting the fish out of the community. 
Social norms compelling fishers to want to work under a fishing permit also seem to play a role in reducing the costs associated with organizing into a co-op. In isolated settings, the likelihood of state enforcement is too low to entirely explain fishers' motivations for acquiring fishing permits (Johnson 2010). "Working right" seems to be an important norm for some communities, along with the potential future benefits that a permit might bring, e.g., access to subsidies or equipment and legitimation as stakeholders in fisheries.

In contrast to cooperative strategies of self-governance, noncooperative patron-client arrangements seem to be better fitted for an opposite set of conditions: settings where fishers find low transaction costs of commercialization linked to weaker motivation to work under a fishing permit, and where the characteristics of the social setting might be less conducive to the development or maintenance of strong traditions of collective action. These conditions are likely found more often in places offering low entry barriers to outsiders, making it easier for middlemen and other outsiders to establish themselves. Places with high immigration rates can be characterized by weak norms of trust and reciprocity, or overall low social capital (Putnam et al. 1994), making it challenging for fishers to develop stable enough relationships to invest in building fishing co-ops. Communities with these characteristics just described are common in other locations in the Gulf of California outside of the study area, such as Kino Bay (Cinti et al. 2010).

In sum, our findings suggest that the two different forms of self-governance of SSFs we examined could be associated with a spatial dimension of social-ecological fit. Further exploring this issue could help determine where co-ops versus patron-client self-governance arrangements are more likely to be established and sustained, and help determine where promoting the establishment of co-ops would offer a better conservation potential to local fishers.

\section{Which form of self-governance is better fitted to promote conservation behaviors?}

The two different self-governance arrangements, co-ops and patron-client structures, offer different potential for adaptation and conservation. Patron-client structures are usually thought to be less conducive to the development of resource stewardship and comanagement for conservation (Johnson 2010) than co-ops are (Ovando et al. 2012). In forest commonpool resources, market access has been found to reduce the durability of cooperative institutions for resource management (Agrawal 2001, Young 1994). Cinner et al. (2007) have reported that fishing communities located far from markets are able to develop customary management systems, e.g., customary fishery closures, whereas those closer to markets fail more often, and even show signs of overexploitation (Cinner and McClanahan 2006). Although our study finds that distance to markets is only one of a larger set of transaction costs of commercialization, under a patron-client structure, incentives for governing fish production and for understanding of ecosystem dynamics can be easily decoupled in fishers' decision-making processes (Crona et al. 2010). Middlemen face strong incentives to supply the demand for fish and do not pay the costs of ecosystem degradation, because they can move unrestricted to other areas, acting as roving bandits (Berkes et al. 2006).

The ability to adapt to environmental variability is usually embedded in the knowledge and understanding that fishers develop through experimentation in daily fishing activities (Berkes 2008). Patron-client structures offer few incentives for conservation. Fishers holding knowledge about resource dynamics have less decision-making power in their relation with fish buyers, particularly if these patrons provide fishers with fishing permits, credits, loans, or fishing equipment. Thus, discussions of long-term concerns about resource depletion will be secondary to fishers' short-term concerns of building a relationship with a fish buyer to secure adequate buying terms for their catch.

In contrast, cooperative governance structures offer the possibility that fishers might find it in their interest to internalize and integrate different aspects of the fishing activity, like processing, transportation, and even commercialization. When this happens, the likelihood increases that they will incorporate relevant knowledge for the maintenance of ecosystem functions into decision making. Unlike the co-ops in this study, all of which are 10 years old or less (Table 1), older co-ops in other parts of the Gulf of California have shown themselves capable of increasing their administrative expertise and incorporating more production, processing, and marketing activities (Castañeda et al. 2012, Méndes-Sánchez 2012). Besides following a vertically integrated business model, the federation of fishing co-ops on the north Pacific coast of Mexico (FEDECOOP) makes regular investments in the maintenance of ecosystem function by closing some abalone reefs and taking the lead in monitoring and enforcement of these areas inside of their fishing concessions (McCay et al. 2013). A diverse range of conservation benefits has also been documented in the Chilean context (Gelcich et al. 2008), and by Ovando et al. (2012), more generally.

\section{Policy future}

In Mexico, the 1992 fisheries reforms made it possible for fishers as well as nonfishers to obtain fishing permits without having to belong to a co-op, effectively formalizing the existence of patron-client governance arrangements as a common form of SSFs governance. We anticipate that patronclient strategies will become an even more common form of organization that fishers will adopt in the future, as the transaction costs of commercialization decrease, for instance, as a result of coastal development, urbanization, and road development toward coastal areas. 
These scenarios underline the need to better highlight rather than obscure the crucial link that middlemen, fish buyers, and patrons play in SSFs stewardship. Policy makers should also recognize the important microcredit and insurance services that middlemen provide to fishers, including the fact that state institutions are unlikely to be able to match the individually tailored level at which patrons can provide these services to fishers. To better determine what kinds of policies and property rights can increase the conservation potential of noncooperative arrangements is an important area of policy research in the globalization era.

Finally, although this study has provided an in-depth look into small-scale communities in one particular region of Mexico, the results underscore the importance of examining linkages between broader-level economic and policy changes and local-level institutional diversity. Although the state still reserves some high-value species such as lobster and abalone exclusively for co-ops (McCay et al. 2013), the fisheries policy reform of 1992 was part of a broader trend in Mexico toward trade liberalization, encouragement of private investment, and rollback of state interventionism in the primary sector (Young 2001). Acknowledging cross-scale connections such as these can provide insight into how state and global political change may have consequences for resource governance, even in small-scale and remote settings.

Responses to this article can be read online at: http://www.ecologyandsociety.org/issues/responses. php/5673

\section{Acknowledgments:}

Financial assistance was kindly provided by the Walton Family Foundation and the David and Lucile Packard Foundation. We remain grateful to Pablo Castro, Elena Finkbeiner, Rocío Rivera, Jesús Bernardo Sanchez, and Norma Sánchez for their assistance in the field and for preliminary analyses. For their editorial and map-making support at different junctures of the publication process, we thank Rocio Covarrubias, Morgan Gopnik, Patty Lezotte, Doug Perron, and Siaontoni Sarkar. Without the cooperation of fishers and fish-buyers, it would have been impossible to conduct this study.

\section{LITERATURE CITED}

Agrawal, A. 2001. Common property institutions and sustainable governance of resources. World Development 29:1649-1672. http://dx.doi.org/10.1016/S0305-750X(01)00063-8

Amarasinghe, O. 2006. Cooperation in a context of crisis: public private management of marine fisheries in South Asia.
IDPAD working paper series, 5. Indo-Dutch Programme on Alternatives in Development, The Netherlands.

Armitage, D., F. Berkes, and N. Doubleday, editors. 2007. Adaptive co-management: collaboration, learning, and multilevel governance. University of British Columbia Press, Vancouver, British Columbia, Canada.

Barrett, G., and R. Apostle. 1989. Formal and informal economic ties between fishing boat captains and fish buyers in Nova Scotia. Canadian Journal of Sociology 14:1-23. http:// www.jstor.org/stable/3341081

Baticados, D. B. 2004. Fishing cooperatives' participation in managing nearshore resources: the case in Capiz, central Philippines. Fisheries Research 67:81-91. http://dx.doi. org/10.1016/j.fishres.2003.07.005

Berkes, F. 2008. Sacred ecology: traditional ecological management and resource management. Taylor and Francis, Philadelphia, Pennsylvania, USA.

Berkes, F., and C. Folke, editors. 1998. Linking social and ecological systems: management practices and social mechanisms for building resilience. Cambridge University Press, Cambridge, UK.

Berkes, F., T. P. Hughes, R. S. Steneck, J. A. Wilson, D. R. Bellwood, B. Crona, C. Folke, L. H. Gunderson, H. M. Leslie, J. Norberg, M. Nystrom, P. Olsson, H. Österblom, M. Scheffer, and B. Worm. 2006. Globalization, roving bandits, and marine resources. Science 311:1557-1558. http://dx.doi.org/10.1126/ science. 1122804

Castañeda, N. L., S. Guido, and F. Medina. 2012. Cooperativas pesqueras exitosas en Sinaloa: lecciones para aprender y compartir. Universidad Autónoma de Sinaloa, Mazatlán, Sinaloa, Mexico.

Cheong, S. 2004. Managing fishing at the local level: the role of fishing village cooperatives in Korea. Coastal Management 32:191-201. http://dx.doi.org/10.1080/08920750490276254

Chuenpagdee, R., editor. 2011. World small-scale fisheries: contemporary visions. Eburon, Delft, the Netherlands.

Cinner, J., and T. R. McClanahan. 2006. Socioeconomic factors that lead to overfishing in a small-scale coral reef fishery in Papua New Guinea. Environmental Conservation 33:73-80. http://dx.doi.org/10.1017/S0376892906002748

Cinner, J. E., S. G. Sutton, and T. G. Bond. 2007. Socioeconomic thresholds that affect use of customary fisheries management tools. Conservation Biology 21 (6):1603-1611. http://dx.doi.org/10.1111/j.1523-1739.2007.00796. $\underline{\mathrm{X}}$

Cinti, A., W. Shaw, R. Cudney-Bueno, and M. Rojo. 2010. The unintended consequences of formal fisheries policies: social disparities and resource overuse in a major fishing 
community in the Gulf of California, Mexico. Marine Policy 34:328-339. http://dx.doi.org/10.1016/j.marpol.2009.08.002

Crona, B., M. Nystrom, C. Folke, and N. Jiddawi. 2010. Middlemen: a critical social-ecological link in coastal communities of Kenya and Zanzibar. Marine Policy 34:761-771. http://dx.doi.org/10.1016/j.marpol.2010.01.023

Deacon, R. T., D. P. Parker, and C. Costello. 2008. Improving efficiency by assigning harvesting rights to fishery cooperatives: evidence from the Chignik salmon co-op. Arizona Law Review 50:479-510.

Delgado, C. L., N. Wada, M. W. Rosegrant, S. Meijer, and M. Ahmed. 2003. Fish to 2020: supply and demand in changing global markets. WorldFish Center Technical Report 62. International Food Policy Research Institute Washington, D. C., USA, and WorldFish Center, Penang, Malaysia. [online] URL: http://www.ifpri.org/sites/default/files/pubs/pubs/books/ fish2020/oc44.pdf

Dominguez, Q. R. D. 1995. Papel y transformación de las unidades de producción pesquera ejidales en el sector halieútico Yucatán, México. Universidad Autónoma de Yucatán, Yucatán, México.

Folke, C., S. Carpenter, T. Elmqvist, L. H. Gunderson, C. S. Holling, and B. Walker. 2002. Resilience and sustainable development: building adaptive capacity in a world of transformations. AMBIO: A Journal of the Human Environment 31:437-440.

Food and Agriculture Organization of the United Nations (FAO). 1971. Manual on fishermen's cooperatives. FAO, Rome, Italy.

Gelcich, S., N. Godoy, L. Prado, and J. C. Castilla. 2008. Addon conservation benefits of marine territorial user rights fishery policies in central Chile. Ecological Applications 18:273-281. http://dx.doi.org/10.1890/06-1896.1

International Co-operative Alliance (ICA). 2010. Cooperative identity, values and principles ICA, Geneva, Switzerland. [online] URL: http://www.ica.coop/es/node/1625

Jentoft, S. 1986. Fisheries co-operatives: lessons drawn from international experiences. Canadian Journal of Development Studies 7:197-209. http://dx.doi.org/10.1080/02255189.1986.9670154

Johnson, D. S. 2010. Institutional adaptation as a governability problem in fisheries: patron-client relations in the Junagadh fishery, India. Fish and Fisheries 11:264-277. http://dx.doi. org/10.1111/j.1467-2979.2010.00376.x

Juárez-Torres, M., M. L. Flores-Escobar, and J. L. Martínez. 2007. El sector pesquero en México. Financiera Rural, D.F., México.

Kurien, J. 1988. The role of fishermen's organizations in fisheries management of developing countries (with particular reference to the Indo-Pacific region). Food and Agriculture Organization of the United Nations, Rome, Italy.

Lejano, R. P., and A. Ocampo-Salvador. 2006. Context and differentiation: comparative analysis of two community-based fishers' organizations. Marine Policy 30:726-736. http://dx. doi.org/10.1016/j.marpol.2005.12.001

Lindenthal, R. 1994. Cooperatives and employment in developing countries. Publications of the Cooperative Branch, International Labor Organization, Geneva, Switzerland.

Marín, A., S. Gelcich, J. Castilla, and F. Berkes. 2012. Exploring social capital in Chile's coastal benthic comanagement system using a network approach. Ecology and Society 17(1): 13. http://dx.doi.org/10.5751/ES-04562-170113

McCay, B. J. 1980. A fishermen's cooperative, limited: indigenous resource management in a complex society. Maritime Anthropology 53(1):29-38. http://dx.doi. org/10.2307/3317878

McCay, B. J., F. Micheli, G. Ponce-Díaz, G. Murray, G. Shester, S. Ramirez-Sanchez, and W. Weisman. 2013. Cooperatives, concessions, and co-management on the Pacific Coast of Mexico. Marine Policy. In press. http://dx.doi. org/10.1016/j.marpol.2013.08.001

McGoodwin, J. R. 1980. Mexico's marginal inshore Pacific fishing cooperatives. Anthropological Quarterly 53(1):39-47. http://dx.doi.org/10.2307/3317879

Méndes-Sánchez, F. A. 2012. Co-management and smallscale fisheries in Mexico: the case of a fishers' cooperative in Cedros and San Benito islands. Thesis. The University of Auckland, Auckland, New Zealand.

Merlijn, A. G. 1989. The role of middlemen in small-scale fisheries: a case study of Sarawak, Malaysia. Development and Change 20:683-700. http://dx.doi.org/10.1111/j.1467-7660.1989. tb00362.x

Ostrom, E. 2009. A general framework for analyzing sustainability of social-ecological systems. Science 325:419-422. http://dx.doi.org/10.1126/science.1172133

Ovando, D. A., R. T. Deacon, S. E. Lester, C. Costello, T. Van Leuvan, K. McIlwain, C. Kent Strauss, M. Arbuckle, R. Fujita, S. Gelcich, and H. Uchida. 2012. Conservation incentives and collective choices in cooperative fisheries. Marine Policy 37:132-140. http://dx.doi.org/10.1016/j.marpol.2012.03.012

Pedroza, C. 2013. Middlemen, informal trading and its linkages with IUU fishing activities in the port of Progreso, Mexico. Marine Policy 39:135-143. http://dx.doi.org/10.1016/ j.marpol.2012.10.011

Petterson, J. S. 1980. Fishing cooperatives and political power: a Mexican example. Anthropological Quarterly 53(1):64-74. http://dx.doi.org/10.2307/3317882 
Poggie, J. J., R. B. Pollnac, and M. Fierro. 1988. Factors influencing the success of fishermen's cooperatives in Ecuador. Marine Resource Economics 5:231-242.

Pollnac, R. B. 1985. Social and cultural characteristics of small-scale fishery development. Pages 189-223 in M. M. Cernea, editor. Putting people first: sociological variables in rural development. World Bank, Washington, D.C., USA.

Putnam, R. D., R. Leonardi, and R. Nanetti. 1994. Making democracy work: civic traditions in modern Italy. Princeton University Press, Princeton, New Jersey, USA.

Ruddle, K. 2011. "Informal" credit systems in fishing communities: issues and examples from Vietnam. Human Organization 70:224-232.

Sapovadia, V. K. 2004. Fisherman cooperatives: a tool for socio-economic development. International Institute of Fisheries Economics \& Trade Conference, July 2004, Japan. [online] URL: http://papers.ssrn.com/sol3/papers.cfm? abstract id $=954986$

Stuster, J. 1980. "Under the thumb" while "one hand washes the other;" traditional market relations in a California commercial fishing community. Anthropological Quarterly 53:4-11. http://dx.doi.org/10.2307/3317875

Toledo, A., and L. Bozada. 2002. El delta del río Balsas: medio ambiente, pesquerías y sociedad. Instituto Nacional de Ecología y El Colegio de Michoacán, Zamora, Michoacán, Mexico.

Unal, V., M. Yercan, H. Guclusoy, and H. Goncuoglu. 2009. A better understanding of fishery cooperatives in the Aegean, Turkey. Journal of Animal and Veterinary Advances 8:1361-1366.

Wang, N. 1999. Transaction costs and the structure of the market: a case study. American Journal of Economics and Sociology 58:783-805. http://dx.doi.org/10.1111/j.1536-7150.1999. $\underline{\text { tb03394.x }}$

Young, E. 2001. State interventionism and the abuse of the commons: fisheries development in Baja California Sur, Mexico. Annals of the Association of American Geographers 91(2):283-306.

Young, K. R. 1994. Roads and the environmental degradation of tropical montane forests. Conservation Biology 8:972-976. http://dx.doi.org/10.1046/j.1523-1739.1994.08040972.x

Young, O. R. 2002. The institutional dimensions of environmental change: fit, interplay and scale. MIT Press, Cambridge, Massachusetts, USA. 
Appendix 1. Summary of survey questions by topic

Table A1.1 Survey overview

\begin{tabular}{|c|c|}
\hline Question category & Topics \\
\hline General information & $\begin{array}{l}\text { Home community } \\
\text { Age } \\
\text { Education Level } \\
\text { Family and marital status } \\
\text { Years as a fisher } \\
\text { Co-op membership } \\
\text { Co-op name } \\
\text { Land and property ownership } \\
\text { Access to social services } \\
\text { Alternative sources of income }\end{array}$ \\
\hline Fishing activities & $\begin{array}{l}\text { Fishing resources targeted } \\
\text { Fishing seasons } \\
\text { Fishing gear used } \\
\text { Commercialization } \\
\quad \text { Market destinations } \\
\quad \text { Market prices } \\
\quad \text { Product form } \\
\text { Biological/ecological knowledge }\end{array}$ \\
\hline Fishing resources & $\begin{array}{l}\text { Species targeted } \\
\text { Biological/ecological knowledge of species } \\
\text { Season and areas of reproduction } \\
\text { Perceptions of change over time } \\
\text { Fishing resources and fishing areas }\end{array}$ \\
\hline Organization & $\begin{array}{l}\text { Permit ownership } \\
\text { Equipment ownership } \\
\text { Gear, motor, boat } \\
\text { Fishing crews } \\
\text { Current and past crews } \\
\text { Source of inputs (gas, gear, supplies) } \\
\text { Co-op membership } \\
\text { Patron-client relations } \\
\text { Advantages and disadvantages } \\
\end{array}$ \\
\hline Information & $\begin{array}{l}\text { Sources of information } \\
\text { Fisheries information } \\
\text { Regulatory information }\end{array}$ \\
\hline Perspectives & $\begin{array}{l}\text { Problems and issues in the region } \\
\text { Proposed solutions }\end{array}$ \\
\hline
\end{tabular}


Appendix 2. Alternative hypotheses, measures, and findings from survey response data $(n=86)$

\section{Price premium}

Scholars have reported that fishers can obtain better prices for their catch as part of co-ops than working independently, particularly when they have dedicated personnel who are in charge of marketing and commercialization activities (McCay 1980, Petterson 1980).

Hypothesis: Fishers organize around co-ops in order to increase their leverage to negotiate and obtain higher market prices.

Measures and findings: Looking at the market price that fishers were paid per kilogram of the most important commercial species in the region (red snapper, Lutjanus peru), we found no significant difference between price received by co-op members and price received by nonmembers $(\mathrm{p}>0.1$, Table A2.1).

\section{Access to fishing gear and other means of production}

Authors have reported that in other fishing co-ops in the Gulf of California region, co-ops own the boats, gear, and other technologies needed for fishing and suggest this might be a strong incentive to join a co-op for fishermen (Castañeda et al. 2012, McCay et al. 2013).

Hypothesis: Fishers organize around fishing co-ops to gain access to fishing gear and other means of production that are owned in common by the co-op.

Measures and findings: The proportion of fishers owning their own fishing means of production (boats, motors, and gear) did not differ between co-operative and non-cooperative fishers ( $p$ > 0.1 , Table A2.2).

\section{Access to diverse fishing gears}

Given that more than 46 species are harvested in the Corridor region, we also tested for the possibility that fishers chose cooperative vs. non-cooperative strategies based on the need to employ a diversity of fishing gears in order to be successful harvesting multiple species. Co-ops targeting multi-specific fisheries and where fishing gear is owned by the co-op such as reported by McCay et al (2013), can constitute better vehicles for fishers to gain access to a diversity of fishing gear that otherwise would be very expensive for an individual fisher to obtain.

Hypothesis: Fishers operating in a multi-specific fishery will have incentives to pool their gear instead of buying it individually.

Measures and findings: Participatory observations and informal interviews suggest that fishers treat their gear as private property and there is no tradition of sharing it, even among members of 
the same co-op. These assertions were corroborated, as we found no significant differences between fisher groups regarding the number of gear types they use $(p>0.1$, Table A2.1).

\section{Access to information}

Deacon et al. (2008) report that members of fishing co-ops in the Chignik Salmon fishery in Alaska shared information on stock locations significantly more than fishermen not organized in co-ops. Baticados (2008), on the other hand, did not find co-ops to be a source of information on regulations particularly because some aimed to serve only a basic economic function. In Mexico, only fishers formally organized in a co-op or owning a fishing permit are considered legal stakeholders and therefore are the most likely recipients of information about regulations and management from fisheries authorities (Cinti et al. 2010).

Hypothesis: Fishers organize around fishing co-ops to gain access to information related to governmental regulations and fishing.

Measures and findings: Survey respondents listed sources from which they receive information about regulations and fishing. Of nine sources of information surveyed, six sources of information (federal fisheries agency; NGOs; radio; fishers from the same community as the respondent; other fishers in general; and fish buyers) showed no significant difference in usage between co-op and non-co-op fishers $(p>0.1)$. Information from meetings was demonstrated to be a source used more by co-op members than non-co-op fishers $(\mathrm{p}<0.01)$. Also, municipal and state authorities were information sources used more by co-op members than non co-op fishers. Finally, fishers from outside of respondent's community were an information source used more by non-member fishers than by co-op members $(\mathrm{p}<0.05$, Table A2.3).

The relationship between co-op membership and access to information was also tested using the number of species targeted, under the assumption that targeting a greater number of species is associated with increased information needs, for example in order to know where the fish are and to comply with existent regulations. We found no difference between co-op members and nonmember fishers in terms of the number of species fished, $(p>0.1)$ with both groups averaging close to eight targeted species (Table A2.1). 
Table A2.1 Comparing cooperative and non-cooperative fishers: Student's t-tests

\begin{tabular}{|c|c|c|c|c|}
\hline Hypothesis & Fishers in co-ops & $\begin{array}{c}\text { Fishers not in } \\
\text { co-ops }\end{array}$ & $\mathrm{p}$-value & conclusion \\
\hline $\begin{array}{l}\mathrm{H}_{\mathrm{a}}: \text { Average } \\
\text { price/kilo } \\
\text { Huachinango } \\
\text { differs } \\
\mathrm{H}_{0}: \text { No price } \\
\text { difference }\end{array}$ & $\begin{array}{c}\text { Average price: } 34.6 \\
\text { (Mexican Pesos) }\end{array}$ & $\begin{array}{c}\text { Average price: } 32.5 \\
\text { (Mexican Pesos) }\end{array}$ & $\mathrm{p}=0.248$ & $\begin{array}{l}\text { Do not } \\
\text { reject } \mathrm{H}_{0}\end{array}$ \\
\hline $\begin{array}{l}\mathrm{H}_{\mathrm{a}}: \text { Average } \\
\text { number of species } \\
\text { fished differs } \\
\mathrm{H}_{0}: \text { No difference in } \\
\text { number of species } \\
\text { fished }\end{array}$ & $\begin{array}{l}\text { Average number of } \\
\text { species: } 7.80\end{array}$ & $\begin{array}{l}\text { Average number of } \\
\text { species: } 7.74\end{array}$ & $\mathrm{p}=0.922$ & $\begin{array}{l}\text { Do not } \\
\text { reject } \mathrm{H}_{0}\end{array}$ \\
\hline $\begin{array}{l}\mathrm{H}_{\mathrm{a}}: \text { Average } \\
\text { number gear types } \\
\text { used differs } \\
\mathrm{H}_{0}: \text { No difference in } \\
\text { number of gear } \\
\text { types used }\end{array}$ & $\begin{array}{c}\text { Average number of } \\
\text { gear types: } 1.36\end{array}$ & $\begin{array}{c}\text { Average number of } \\
\text { gear types: } 1.57\end{array}$ & $\mathrm{p}=0.194$ & $\begin{array}{l}\text { Do not } \\
\text { reject } \mathrm{H}_{0}\end{array}$ \\
\hline
\end{tabular}


Table A2.2 Comparing cooperative and non-cooperative fishers' gear ownership:

Chi-square tests

\begin{tabular}{|c|c|c|c|c|}
\hline Hypothesis & Fishers in co-ops & $\begin{array}{c}\text { Fishers not in } \\
\text { co-ops }\end{array}$ & p-value & conclusion \\
\hline $\begin{array}{l}\mathrm{H}_{\mathrm{a}}: \text { Fishers in co- } \\
\text { ops will own motor } \\
\text { more often } \\
\mathrm{H}_{0}: \text { No difference in } \\
\text { motor ownership } \\
\text { between groups }\end{array}$ & $\begin{array}{l}\text { Proportion owning } \\
\text { motor: } 18 / 35\end{array}$ & $\begin{array}{l}\text { Proportion owning } \\
\text { motor: } 22 / 48\end{array}$ & 0.749 & $\begin{array}{l}\text { Do not } \\
\text { reject } \mathrm{H}_{0}\end{array}$ \\
\hline $\begin{array}{l}\mathrm{H}_{\mathrm{a}}: \text { Fishers in co- } \\
\text { ops will own a boat } \\
\text { more often } \\
\mathrm{H}_{0}: \text { No difference in } \\
\text { boat ownership } \\
\text { between groups }\end{array}$ & $\begin{array}{l}\text { Proportion owning } \\
\text { boat: } 17 / 35\end{array}$ & $\begin{array}{l}\text { Proportion owning } \\
\text { boat: } 23 / 48\end{array}$ & 1.000 & $\begin{array}{l}\text { Do not } \\
\text { reject } \mathrm{H}_{0}\end{array}$ \\
\hline $\begin{array}{l}\mathrm{H}_{\mathrm{a}}: \text { Fishers in co- } \\
\text { ops will own gear } \\
\text { more often } \\
\mathrm{H}_{0}: \text { No difference in } \\
\text { boat ownership } \\
\text { between groups }\end{array}$ & $\begin{array}{l}\text { Proportion owning } \\
\text { gear: } 28 / 35\end{array}$ & $\begin{array}{l}\text { Proportion owning } \\
\text { gear: } 23 / 48\end{array}$ & 0.322 & $\begin{array}{l}\text { Do not } \\
\text { reject } \mathrm{H}_{0}\end{array}$ \\
\hline
\end{tabular}

Note: $\mathrm{n}=83$ due to 3 missing responses. 
Table A2.3 Comparing cooperative and non-cooperative fishers' information sources:

Chi-square tests

\begin{tabular}{|c|c|c|c|c|}
\hline $\begin{array}{c}\text { General Information } \\
\text { Hypothesis: }\end{array}$ & $\begin{array}{l}\text { Fishers in } \\
\text { co-ops }\end{array}$ & $\begin{array}{l}\text { Fishers not in } \\
\text { co-ops }\end{array}$ & p-value & conclusion \\
\hline $\begin{array}{l}\mathrm{H}_{\mathrm{a}} \text { : Fishers in co-ops will } \\
\text { receive information from the } \\
\text { sources listed below more } \\
\text { often than other fishers } \\
\mathrm{H}_{0} \text { : No difference between } \\
\text { co-op members and other } \\
\text { fishers in use of information } \\
\text { sources }\end{array}$ & $\begin{array}{l}\text { Proportion that } \\
\text { use information } \\
\text { source }\end{array}$ & $\begin{array}{l}\text { Proportion that } \\
\text { use information } \\
\text { source }\end{array}$ & --- & --- \\
\hline Federal fisheries authorities & $5 / 37$ & $9 / 48$ & 0.518 & $\begin{array}{l}\text { Do not } \\
\text { reject } \mathrm{H}_{0}\end{array}$ \\
\hline $\mathrm{NGO}$ & $9 / 37$ & $9 / 48$ & 0.255 & $\begin{array}{l}\text { Do not } \\
\text { reject } \mathrm{H}_{0}\end{array}$ \\
\hline $\begin{array}{l}\text { Municipal and state } \\
\text { authorities }\end{array}$ & $15 / 37$ & $9 / 48$ & 0.027 & Reject $\mathrm{H}_{0}$ \\
\hline Fish buyers & $12 / 37$ & $9 / 48$ & 0.147 & $\begin{array}{l}\text { Do not } \\
\text { reject } \mathrm{H}_{0}\end{array}$ \\
\hline Other fishers & $15 / 37$ & $14 / 48$ & 0.273 & $\begin{array}{r}\text { Do not } \\
\text { reject } \mathrm{H}_{0}\end{array}$ \\
\hline $\begin{array}{l}\text { Fishers from the same } \\
\text { community }\end{array}$ & $19 / 37$ & $27 / 48$ & 0.653 & $\begin{array}{l}\text { Do not } \\
\text { reject } \mathrm{H}_{0}\end{array}$ \\
\hline $\begin{array}{l}\text { Fishers from a different } \\
\text { community }\end{array}$ & $6 / 37$ & $20 / 48$ & 0.012 & $\begin{array}{c}\text { Reject } \\
\mathrm{H}_{0}^{*}\end{array}$ \\
\hline Meetings & $15 / 37$ & $4 / 48$ & 0.0004 & Reject $\mathrm{H}_{0}$ \\
\hline AM/FM Radio & $23 / 37$ & $27 / 48$ & 0.583 & $\begin{array}{l}\text { Do not } \\
\text { reject } \mathrm{H}_{0}\end{array}$ \\
\hline
\end{tabular}

*Although $\mathrm{H}_{0}$ is rejected because the test was significant at the $\mathrm{p}<0.05$ level, co-op members used this information source less than non-member fishers, thus the test cannot be interpreted as supporting $\mathrm{H}_{\mathrm{a}}$. Note: $\mathrm{n}=83$ due to 3 missing responses. 
Appendix 3. Commercialization transaction costs and fishing co-ops

\section{Description of the factors affecting the transaction costs of commercialization}

Below we list and describe the factors thought to influence fishers' costs to reach the first point of commercialization for their products in the study area. These factors were determined based on long-term participant observation conducted in each community. All factors are grouped in Table A3.1:

Closest point of commercialization: Defined as the main closest point of sale or commercialization for most fishers in each community.

Distance: We provide the best approximation available of distance in $\mathrm{Km}$ either by land or sea to reach the first point of commercialization. Note that in most cases, significant portions of land travel are conducted on primitive dirt roads. Please refer to Figure 1 for the location of each market destination.

Presence of fish buyers: The more frequent the presence of a fish buyer to purchase fishers' catch the lower the costs of reaching the first point of commercialization for the fishers because they do not need to transport the catch themselves. We label "Yes" a constant and reliable presence of fish buyers in any given community and "No" meant a rare or unreliable presence of fishbuyers. "Sometimes" indicated an in-between constant and rare, but still unreliable presence of fishbuyers.

Costs of land travel: Incorporates perceptions of costs related to ice provision for transportation, fuel and time associated with the frequency at which fishers in those communities need to use their own vehicles (or those of the co-op) to transport their catch to the first point of commercialization, as well as the associated maintenance costs related to travel on primitive dirt roads. In this region conditions are highly variable depending or rains and other weather events. Primitive road conditions increase general vehicle maintenance costs, the use of spare parts, already hard to get in this region, and thus, vehicle reliability and general availability in any given community. Gray cells in Table A3.1 indicate where this type of cost does not apply.

Costs of sea travel: Several communities transport their catch by sea to reach the first point of commercialization. This factor incorporates perceptions of costs related to ice provision for transportation, fuel and time needed to be spent travelling by sea. Gray cells indicate where this type of cost does not apply. 
Table A3.1 Closest point of commercialization per community and the factors affecting the transaction costs for reaching them in the study area

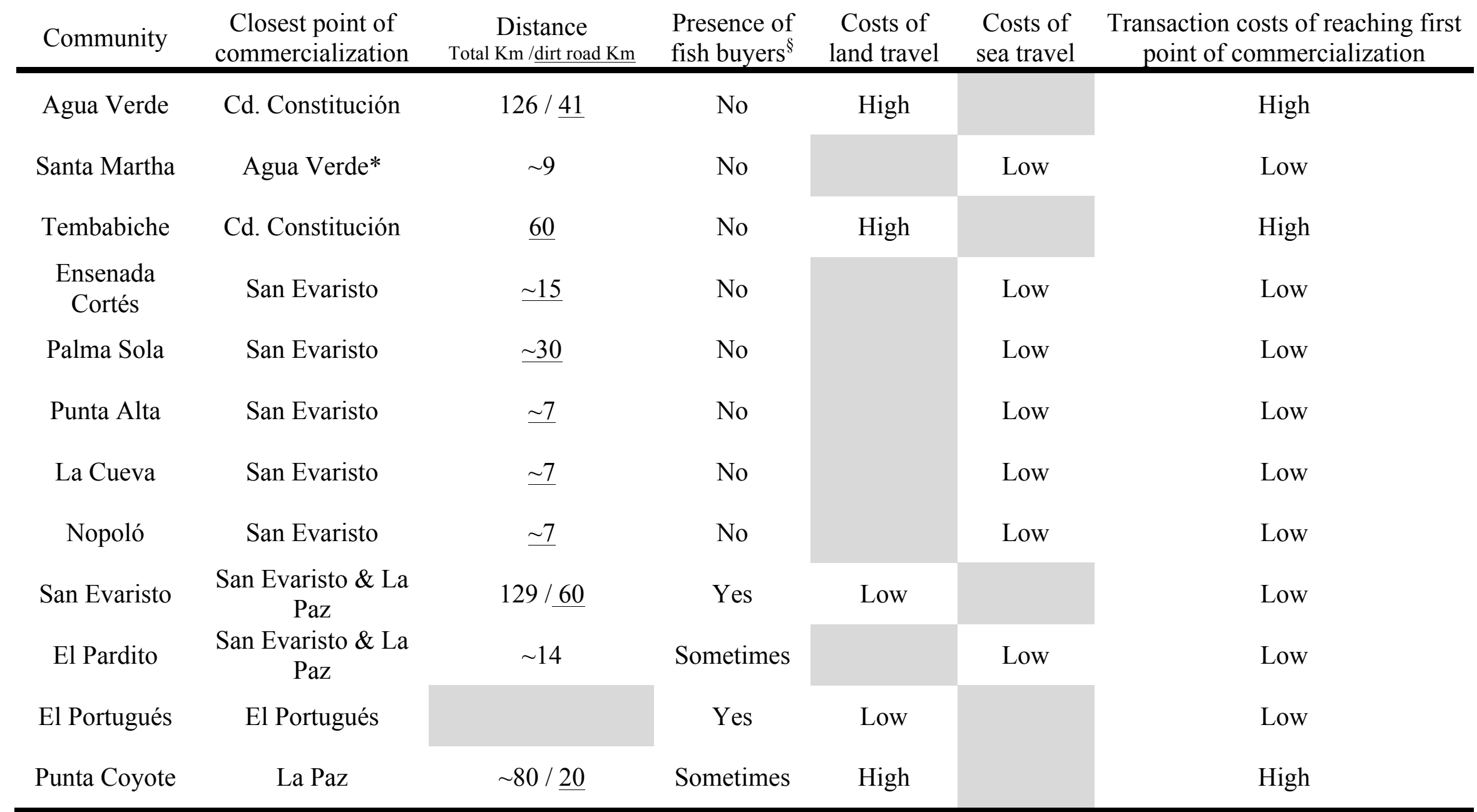

Notes: § Presence of fishbuyers in any given community is very dynamic. We define "yes" as a constant, reliable presence, and "No" as rare or not reliable. *Agua Verde is not a point of commercialization, but it is the place where Santa Martha fishers take their catch and from there is taken to Cd. Constitución. Gray boxes indicate situations where the parameter does not apply either because there is no need to travel, either by land or sea to the first point of commercialization. 